large device carrying 1,000 telephone circuits) and on the German plans for television satellites. This project relies on obtaining the improved ELDO vehicle for launching from the new French equatorial range in Guiana during 1970, but the first full-scale European geostationary satellites, for which the ELDO vehicle is being redesigned, are not now expected till 1971. Both the European projects are concerned with the commercial applications of space communications and have an eye on the 1969 re-negotiation of the Intelsat agreement.

A British defence space communications system is likely to be operational well before this-during 1968. The speedy execution of this project, which only received the go-ahead a few months ago, is made possible because the two satellites are to be made in the United States (by Philco at a total cost of $\$ 7,600,000$ ) and launched there as well. Skynet, as the project is named, will provide a geostationary satellite over the Indian Ocean for maintaining communications with British forces, chiefly east of Suez. The location of the British built ground stations defines the coverage; these are at Christchurch, Hants (SRDE), in Cyprus and Singapore, and aboard the communications ship Wakeful. These have already been built, and experience in operating them with the American Interim Defence Communications Satellite Program (IDCSP) has stimulated the Ministry of Defence to rapid action in estab. lishing an operational network of its own.

\section{Research into Design}

IN 1963 Professor D. R. Harper, of the Department of Building at the University of Manchester Institute of Science and Technology, started some new courses which involve research into various aspects of design and technological change. Two reports have now been issued detailing progress since then (Design Research Reports, 1 and 2) and they show the all embracing range of work which is undertaken at the institute. As the first report admits, the work defies conventional classification, and five new categories have been invented to describe it: design methods, technological change, user requirements, human performance, and building systems. Even this is not enough, and readers looking for something which is relevant to their subject are simply advised to read right through the reports.

Most of the projects are agreeably down to earthparticularly the one devoted to discovering the variation in arm and leg lengths of the largest body sizes commonly met with among car users. This is related to another project in which the internal dimensions of small cars are determined by the method of fitting trials, and to a project on car seating. The design of operating theatre tables, hospital bedsteads and industrialized buildings is also being studied, while bath evaluation is a project which large users may feel is long overdue.

Some of the projects are more directly physiological, concerned with human reaction times, auditory diserimination, and the retention of complex stimuli. Others are obviously long term; one, by Dr J. C. Jones, is concerned with the effects of designing, including side-effects such as sonic bangs and road accidents. There seems little danger that the institute at Manchester will become unduly academic about the problems involved, however, as long as it continues to work on problems as practical as that of refuse disposal for pedestrian precincts.

\section{Shape of Universities}

THE view that the success of the universities in Britain, the United States and Germany had inspired pressures from outside and particularly from governments was one of the themes of the Queen's Lecture delivered at the University of Belfast on May 23 by Sir Eric Ashby, Master of Clare College, Cambridge. The university, he said, is a mechanism for the inheritance of the western style of civilization. Both in Britain and in the United States, the German idea of the university had been a model for development and a successful one. No longer are universities cared for by patrons. Instead, they are "cultivated as intensive crops, heavily manured and expected to give a high yield essential for the nourishment of the state". The universities, Sir Eric said, must adapt themselves to the consequences of their success or they will be discarded by society.

In a comparison of how the German concept of a university had been transplanted into the American and the British idioms, Sir Eric discussed the attempts made at Harvard University in 1945 to make all students familiar, through formal examined courses, with a body of knowledge, ideas and values which constitute 'the heritage of western civilization' ". Sir Eric said that Harvard eventually realized that this technique had failed. He said that a satisfactory way of requiring students to spend some of their learning time outside their specialty had not yet been evolved, but that American universities were moving towards the involvement of students in studies outside their specialties by interesting them in the impact of their subject on the outside world and by the study of topics in great depth.

\section{The Sequenator} from a Correspondent in Molecular Biology

THE determination of the amino-acid sequences of proteins is a specialized and arduous procedure, but at the same time an increasing number of biochemical and structural problems are turning out to be limited by sequence information. (The X-ray determination of globular protein structures is a conspicuous example.) In the long awaited article in the first issue of the new European Journal of Biochemistry $(1,80 ; 1967)$ Edman. and Begg have described a substantially automated procedure for sequencing, and have applied it to the determination of the sequence of the first 60 residues from the $\mathrm{N}$-terminal end of whale myoglobin. In such an approach the critical requirement is for a stepwise degradation reaction of high efficiency, and Edman and Begg in fact use the well known Edman degradation, hitherto the standard procedure when dealing with short oligopeptides, and achieve yields of more than 98 per cent. Thus after 60 successive degradation cycles the overall yield is greater than 30 per cent.

The apparatus performs just over 15 degradations in 24 hours, and requires some $0.25 \mu$ moles of protein. The final stage of the Edman procedure, the identification of the amino-acid derivative (phenylthiohydantoin), is not included in the automated procedure: instead, serially produced derivatives are all applied 